\title{
Peranan Pupuk Kalsium pada Tanaman Kelapa Sawit (Elaeis guineensis Jacq.) Belum Menghasilkan
}

\section{Role of Calcium Fertilizer on Young Plant of Oil Palm (Elaeis guinensis Jacq.)}

\section{Hupudio Hutomo Widodo ${ }^{1}$, Sudradjat ${ }^{1 *}$}

${ }^{1}$ Departemen Agronomi dan Hortikultura, Fakultas Pertanian, Institut Pertanian Bogor (Bogor Agricultural University), Jl. Meranti, Kampus IPB Darmaga, Bogor 16680, Indonesia Telp.\&Faks.62-251-8629353,e-mail agronipb@indo.net.id

*Penulis untuk korespondensi: sudradjat_ipb@yahoo.com

Disetujui 14 November 2016/ Publish online 8 Desember 2016

\begin{abstract}
The objective of this research was study the effect of calcium fertilization on palm oil aged one year. The experiment was conducted at Teaching Farm of Palm Oil plantation, Jonggol Bogor from March 2013 to March 2014. The design used was completely randomized block design with 3 replications. The treatment consists of 1 factor, namely calcium fertilization with 4 dose levels: without calcium (CaO), $0.6 \mathrm{~kg}(\mathrm{Ca} 1), 1.2 \mathrm{~kg}(\mathrm{Ca} 2)$, and $2.3 \mathrm{~kg}$ (Ca3) of calcium. Each experimental unit consisted of 5 plants so the total of the plant sample was 60 plants. The results showed that the calcium fertilizer did not significantly affect to the growth of plant morphology and physiology.
\end{abstract}

Keywords: calcium, optimal rate, palm oil

\begin{abstract}
ABSTRAK
Penelitian optimasi pupuk kalsium pada kelapa sawit (Elaeis guineensis Jacq.) bertujuan mempelajari pengaruh pemupukan tanaman kelapa sawit belum menghasilkan umur satu tahun. Penelitian dilaksanakan di Teaching Farm Kelapa Sawit Jonggol, Bogor dari bulan Oktober 2013 hingga Maret 2014. Rancangan penelitian yang digunakan adalah Rancangan Kelompok Lengkap Teracak (RKLT) dengan 3 ulangan. Perlakuan terdiri atas 1 faktor, yaitu pemupukan kalsium dengan 4 taraf dosis Ca: tanpa kalsium (Ca0), $0.6 \mathrm{~kg}$ (Ca1), $1.2 \mathrm{~kg}$ (Ca2), dan $2.3 \mathrm{~kg}$ (Ca3) kalsium. Setiap satuan percobaan terdiri atas 5 tanaman sehingga terdapat 60 tanaman contoh. Hasil penelitian menunjukan bahwa pemupukan kalsium tidak berpengaruh nyata terhadap pertumbuhan morfologi dan fisiologi tanaman.
\end{abstract}

Kata kunci : dosis optimum, kalsium, kelapa sawit 


\section{PENDAHULUAN}

Kelapa sawit merupakan salah satu komoditas perkebunan yang mengalami laju pertumbuhan pesat. Peningkatan luas areal terutama dilakukan pada lahan yang kurang subur, karena lahan dengan kesesuaian tinggi digunakan untuk pengembangan tanaman pangan. Upaya yang dilakukan untuk meningkatkan produktivitas tanaman kelapa sawit melalui perbaikan teknologi pemupukan merupakan salah satu cara untuk memenuhi kebutuhan minyak sawit domestik dan ekspor.

Peningkatan produksi dapat dipengaruhi oleh usaha yang dilakukan. Peningkatan tersebut dapat dilakukan dengan intensifikasi. Proses intensifikasi dilakukan mulai tanaman di pembibitan sampai umur tanaman tidak produktif. Faktor yang perlu diperhatikan dalam intensifikasi tersebut salah satunya adalah aspek pemupukan. Kebutuhan hara tanaman yang terus menerus tidak dapat disediakan oleh tanah secara alami, sehingga diperlukan penambahan hara dari luar. Menurut Pahan (2007) manfaat yang diperoleh dari pemupukan diantaranya adalah melengkapi ketersediaan hara di dalam tanah serta menggantikan unsur hara yang hilang karena pencucian dan terangkut pada waktu panen sehingga kondisi tanah baik untuk pertumbuhan dan perkembangan kelapa sawit.

Tanaman tumbuh dengan baik tergantung pada kesuburan tanah. Menurut Risza ( 2010) sifat tanah yang baik mampu menyediakan unsur hara dalam jumlah cukup. Diantara sifat tanah adalah sifat kimia, yaitu derajat kemasaman tanah dan komposisi kandungan hara mineral yang ada. Derajat kemasaman ini berpengaruh terhadap ketersediaan hara yang dapat diserap oleh tanah. Kalsium merupakan unsur hara terpenting setelah unsur esensial $(\mathrm{N}, \mathrm{P}$, dan $\mathrm{K})$ sebagai pasokan nutrisi tanaman. Menurut Plaster (1992) fungsi kalsium pada tanaman digunakan sebagai pembangun dinding sel. Kalsium juga sebagian besar digunakan sebagai kontrol terhadap $\mathrm{pH}$ tanah dan membantu pembentukan agregat tanah, serta, kalsium memiliki peranan dalam pembentukan protein dan pergerakan karbohidrat. Tujuan penelitian adalah mempelajari pengaruh kalsium pada tanaman kelapa sawit umur satu tahun.

\section{BAHAN DAN METODE}

Penelitian ini dilakukan di Teaching Farm kelapa sawit Kampung Malati, Desa Singasari, Kecamatan Jonggol, Bogor, IPB-Cargill. Analisis tanah dilakukan di Balai Penelitian Tanah Bogor.
Penelitian berlangsung pada bulan Maret 2013 hingga Maret 2014. Bahan yang digunakan adalah tanaman kelapa sawit varietas tenera Damimas umur umur 1 tahun setelah pembibitan, pupuk kalsium, urea, SP-36, dan MoP. Peralatan yang digunakan adalah SPAD, jangka sorong digital, timbangan digital, oven dan meteran.

Penelitian ini menggunakan rancangan kelompok lengkap teracak (RKLT) 1 faktor dengan 4 taraf dosis $\mathrm{Ca}$ yaitu tanpa kalsium (Ca0), $0.6 \mathrm{~kg}$ kalsium (Ca1), $1.2 \mathrm{~kg}$ kalsium (Ca2), dan $2.3 \mathrm{~kg}$ kalsium (Ca3). Setiap perlakuan diulang sebanyak 3 kali, dalam satu satuan percobaan terdapat 5 tanaman contoh, sehingga terdapat 60 sampel tanaman. Data di analisis dengan sidik ragam pada taraf uji $\mathrm{F}$ pada $\alpha=5 \%$ jika menunjukkan pengaruh nyata pada peubah yang diamati, dilanjutkan dengan uji Kontras Polinomial Ortogonal (Matjik dan Sumertajaya, 2006).

Persiapan tanaman meliputi pelabelan dan pengendalian gulma. Pemberian label dilakukan untuk menandai tanaman agar memudahkan pada saat aplikasi pupuk dan pengamatan. Tanaman kelapa sawit yang telah berlabel, dilakukan pengendalian gulma pada piringan dengan jarijari $1-1.5 \mathrm{~m}$ hingga kondisi W0. Kegiatan tersebut untuk menghindari persaingan tanaman dengan gulma terhadap serapan hara, serta mencegah adanya penyakit pada tanaman.

Perlakuan pemupukan pertama dilakukan pada 3 bulan setelah penanaman dan perlakuan kedua dilakukan 6 bulan setelah pemupukan pertama. Sebelum pelaksanaan penelitian, pemberian pupuk dasar dilakukan pada setiap lubang tanam pada saat penanaman. Komposisi pupuk dasar, urea, SP-36, dan MoP pertanaman yaitu mengikuti dosis rekomendasi yang diberikan pada kebun pendidikan dan percobaan.

Pemeliharaan tanaman meliputi pengendalian gulma pada piringan dan gawangan, pengendalian hama penyakit serta kastrasi. Pengendalian gulma dilakukan secara manual atau kimia. Pembuangan bunga dan pelepah dilakukan dengan cara didodos. Prinsip peubah yang diamati adalah peubah morfologi dan fisiologi tanaman. Pengamatan peubah morfologi dilakukan satu bulan sekali setelah enam bulan pada pemupukan pertama selama satu tahun. Sedangkan pada peubah fisiologi tanaman pengamatan dilakukan tiga bulan sekali dimulai dari pemupukan pertama.

Pengamatan yang dilakukan meliputi tinggi tanaman, lingkar batang, jumlah pelepah, panjang pelepah, luas daun, tingkat kehijauan daun, dan analisis jaringan tanaman. 
Pengambillan contoh tanah dilakukan pada awal dan akhir percobaan.

\section{HASIL DAN PEMBAHASAN}

Lahan yang digunakan dalam percobaan pada tanaman kelapa sawit belum menghasilkan terdiri dari satu blok yaitu blok perlakuan pupuk kalsium. Analisis tanah diambil dari satu contoh dari beberapa titik di gawangan secara komposit. Analisis tanah yang ada, dinilai dari kriteria penilaian berbagai sifat kimia tanah yang dikeluarkan Pusat Penelitian Tanah (2008). Tekstur tanah pada blok percobaan didominasi oleh kandungan liat $48 \%$, debu $36 \%$, dan pasir $16 \%$. Reaksi kimia pada tanah termasuk sangat masam dengan $\mathrm{pH}(\mathrm{H} 2 \mathrm{O}) 4.2$, Corganik rendah $(1.41 \%)$, kadar $\mathrm{N}$ tersedia rendah $(0.13 \%), \mathrm{P}$ tersedia sangat rendah $(2.1 \mathrm{ppm})$, kadar $\mathrm{K}$ sedang $\left(0.13 \mathrm{cmol}_{\mathrm{c}} \mathrm{kg}^{-1}\right)$, kapasitas tukar kation (KTK) tinggi $\left(26,86 \mathrm{cmol}_{\mathrm{C} \mathrm{kg}}{ }^{-1}\right)$, Ca sedang (7,66 $\left.\mathrm{cmol}_{\mathrm{C}} / \mathrm{kg}\right)$, kejenuhan basa sedang (37\%).

Curah hujan total pada awal perlakuan sampai akhir penelitian (Maret 2013 - Maret 2014) sebesar $3351 \mathrm{~mm} /$ tahun. Walapun total curah hujan tinggi, terdapat 3 bulan kering dalam sebarannya. Rata-rata curah hujan bulanan berkisar antara $60-605.5 \mathrm{~mm}$ perbulan, tertinggi pada bulan januari dengan curah hujan $605.5 \mathrm{~mm}$ dan terendah pada bulan September $60 \mathrm{~mm}$.

\section{Pertumbuhan Tanaman}

Pertumbuhan morfologi tanaman terhadap pemberian kalsium dari 1-12 bulan setelah perlakuan (BSP) menunjukkan peningkatan (Tabel 1). Peningkatan tersebut dapat dilihat pada rata-rata tinggi, lingkar batang, jumlah pelepah, dan panjang pelepah pada pengamatan perlakuan kalsium satu BSP masingmasing $171.9 \pm 24.6 \mathrm{~cm}, 19.6 \pm 1.4 \mathrm{~cm}, 8.3 \pm 1.1$ helai, $135.0 \pm 23.1 \mathrm{~cm}$. Pengamatan pada $12 \mathrm{BSP}$ mengalami peningkatan pada peubah tinggi tanaman, lingkar batang, jumlah pelepah dan panjang pelepah masing-masing $261 \pm 25.9 \mathrm{~cm}$, $77.1 \pm 3.7 \mathrm{~cm}, 30.8 \pm 1.5$ helai, $157.3 \pm 12.6 \mathrm{~cm}$. Rata-rata laju pertumbuhan pada tanggap morfologi tinggi tanaman sebesar $7.4 \mathrm{~cm} /$ bulan, lingkar batang $4.8 \mathrm{~cm} /$ bulan, jumlah pelepah 1.9 helai/bulan, dan panjang pelepah $1.9 \mathrm{~cm} / \mathrm{bulan}$.

Tabel 1. Laju pertumbuhan kelapa sawit TBM 1 selama penelitian

\begin{tabular}{|c|c|c|c|c|}
\hline $\begin{array}{l}\text { Umur } \\
\text { BSP }\end{array}$ & $\begin{array}{l}\text { Tinggi tanaman } \\
(\mathrm{cm})\end{array}$ & $\begin{array}{c}\text { Lingkar batang } \\
(\mathrm{cm})\end{array}$ & $\begin{array}{c}\text { Jumlah pelepah } \\
\text { (helai) }\end{array}$ & $\begin{array}{c}\text { Panjang pelepah } \\
(\mathrm{cm})\end{array}$ \\
\hline 1 & $171.9 \pm 24.6$ & $19.6 \pm 1.4$ & $8.3 \pm 1.1$ & $135.0 \pm 23.1$ \\
\hline 2 & $182.9 \pm 23.9$ & $35.6 \pm 4.9$ & $10.2 \pm 1.3$ & $135.2 \pm 20.5$ \\
\hline 3 & $188.2 \pm 19.8$ & $48.2 \pm 7.1$ & $11.9 \pm 0.9$ & $133.7 \pm 6.9$ \\
\hline 4 & $196.7 \pm 13.9$ & $55.2 \pm 6.8$ & $14.2 \pm 1.4$ & $142.3 \pm 8.8$ \\
\hline 5 & $205.3 \pm 9.9$ & $57.3 \pm 6.9$ & $16.1 \pm 0.9$ & $150.2 \pm 11.5$ \\
\hline 6 & $210.7 \pm 8.8$ & $59.2 \pm 6.6$ & $17.3 \pm 0.9$ & $149.1 \pm 8.4$ \\
\hline 7 & $215.2 \pm 9.9$ & $60.9 \pm 6.3$ & $19.6 \pm 0.9$ & $148.2 \pm 8.3$ \\
\hline 8 & $218.5 \pm 9.6$ & $62.9 \pm 6.5$ & $21.6 \pm 0.9$ & $142.5 \pm 7.5$ \\
\hline 9 & $221.5 \pm 10.6$ & $65.0 \pm 6.6$ & $23.3 \pm 0.9$ & $144.3 \pm 8.1$ \\
\hline 10 & $227.6 \pm 10.6$ & $67.0 \pm 6.7$ & $26.3 \pm 1.1$ & $149.9 \pm 6.3$ \\
\hline 11 & $241.5 \pm 11.1$ & $72.6 \pm 3.5$ & $28.2 \pm 1.1$ & $154.9 \pm 9.6$ \\
\hline 12 & $261.0 \pm 25.9$ & $77.1 \pm 3.7$ & $30.8 \pm 1.5$ & $157.3 \pm 12.6$ \\
\hline Laju per bulan & 7.4 & 4.8 & 1.9 & 1.9 \\
\hline
\end{tabular}

Hasil penelitian menunjukkan pemberian pupuk $\mathrm{Ca}$ tidak memberikan pengaruh nyata pada pertumbuhan tinggi tanaman (Tabel 2). Perbandingan Ca1 sebesar $6.0 \%$ pada 12 BSP terhadap kontrol, sedangkan pada perlakuan $\mathrm{Ca} 2$ lebih tinggi $13.5 \%$ dan $\mathrm{Ca} 3$ lebih tinggi $3.1 \%$ dengan kontrol pada 12 BSP.

Hasil penelitian menunjukkan bahwa pemberian pupuk $\mathrm{Ca}$ tidak memberikan pengaruh pada lingkar batang (Tabel 3). Perlakuan $\mathrm{Ca} 3$ menghasilkan lingkar batang pada 12 BSP
$3.0 \%$ dibandingkan dengan perlakuan $\mathrm{Ca} 0,0.9 \%$ dengan $\mathrm{Ca} 1$ dan $2.0 \%$ dengan $\mathrm{Ca} 2$.

Pemberian pupuk $\mathrm{Ca}$ tidak memberikan pengaruh terhadap jumlah pelepah (Tabel 4). Hasil yang didapatkan menunjukkan pada semua perlakuan memperoleh pertambahan jumlah pelepah pada 12 BSP tidak berbeda jauh dengan perlakuan kontrol. Hal ini berarti tanpa pemberian kalsium, tanaman dapat menghasilkan pelepah dengan baik. 
Tabel 2. Tinggi tanaman sawit pada berbagai dosis kalsium

\begin{tabular}{|c|c|c|c|c|c|c|c|c|c|c|c|c|}
\hline \multirow{2}{*}{$\begin{array}{c}\text { Kalsium } \\
(\mathrm{kg} / \text { pokok })\end{array}$} & \multicolumn{12}{|c|}{ Waktu (BSP) } \\
\hline & 1 & 2 & 3 & 4 & 5 & 6 & 7 & 8 & 9 & 10 & 11 & 12 \\
\hline & \multicolumn{12}{|c|}{------------------------cm------------------------ } \\
\hline 0 & 164.1 & 167.1 & 175.5 & 188.4 & 200.3 & 204.4 & 210.2 & 214.0 & 215.8 & 222.2 & 237.5 & 247.0 \\
\hline 0.6 & 179.5 & 194.0 & 195.6 & 204.5 & 214.8 & 220.1 & 225.7 & 228.5 & 231.9 & 235.9 & 243.2 & 261.9 \\
\hline 1.2 & 177.7 & 186.6 & 190.8 & 195.0 & 201.3 & 205.3 & 208.4 & 212.1 & 217.4 & 221.9 & 240.4 & 280.4 \\
\hline 2.3 & 166.5 & 184.0 & 190.9 & 199.0 & 207.8 & 213.0 & 216.4 & 219.3 & 221.0 & 230.5 & 244.7 & 254.6 \\
\hline Notasi & tn & tn & tn & tn & tn & tn & tn & tn & tn & tn & tn & tn \\
\hline
\end{tabular}

Keterangan : tn : tidak berbeda nyata, BSP: Bulan setelah perlakuan

Tabel 3. Lingkar batang tanaman sawit pada berbagai dosis kalsium

\begin{tabular}{|c|c|c|c|c|c|c|c|c|c|c|c|c|}
\hline \multirow{2}{*}{$\begin{array}{l}\text { Kalsium } \\
\text { (kg/pokok) }\end{array}$} & \multicolumn{12}{|c|}{ Lingkar batang $(\mathrm{cm})$ pada BSP } \\
\hline & 1 & 2 & 3 & 4 & 5 & 6 & 7 & 8 & 9 & 10 & 11 & 12 \\
\hline 0 & 20.3 & 34.1 & 47.6 & 52.2 & 54.5 & 57.5 & 59.7 & 62.22 & 65.3 & 66.8 & 71.3 & 75.9 \\
\hline 0.6 & 20.6 & 38.9 & 52.1 & 56.3 & 59.1 & 60.3 & 60.9 & 62.20 & 63.4 & 65.4 & 71.9 & 77.5 \\
\hline 1.2 & 18.9 & 36.2 & 46.7 & 52.8 & 54.4 & 56.1 & 58.4 & 61.40 & 63.3 & 65.5 & 71.8 & 76.7 \\
\hline 2.3 & 18.5 & 33.3 & 46.5 & 59.5 & 61.1 & 63.0 & 64.9 & 66.00 & 68 & 70.3 & 75.3 & 78.2 \\
\hline Notasi & tn & tn & tn & tn & tn & tn & tn & tn & tn & tn & tn & tn \\
\hline
\end{tabular}

Keterangan : $\mathrm{n}$ : tidak berbeda nyata, BSP: Bulan setelah perlakuan.

Tabel 4. Jumlah pelepah tanaman sawit pada berbagai dosis kalsium

\begin{tabular}{|c|c|c|c|c|c|c|c|c|c|c|c|c|}
\hline \multirow{2}{*}{$\begin{array}{c}\text { Kalsium } \\
\text { (kg/pokok) }\end{array}$} & \multicolumn{12}{|c|}{ Tinggi tanaman $(\mathrm{cm})$ pada BSP } \\
\hline & 1 & 2 & 3 & 4 & 5 & 6 & 7 & 8 & 9 & 10 & 11 & 12 \\
\hline 0 & 8.3 & 10.7 & 12.0 & 14.3 & 16.3 & 17.7 & 20.0 & 22.0 & 23.7 & 26.7 & 28.7 & 31.3 \\
\hline 0.6 & 8.6 & 10.3 & 12.3 & 15.3 & 16.7 & 18.0 & 20.0 & 22.0 & 23.7 & 26.7 & 28.7 & 31.0 \\
\hline 1.2 & 8.6 & 10.3 & 11.7 & 13.0 & 15.3 & 16.7 & 19.0 & 21.0 & 22.7 & 25.7 & 27.7 & 30.3 \\
\hline 2.3 & 7.3 & 9.3 & 11.7 & 14.0 & 16.00 & 17.0 & 19.3 & 21.3 & 23.3 & 26.0 & 27.7 & 30.3 \\
\hline Notasi & tn & tn & tn & tn & tn & tn & tn & tn & tn & tn & tn & tn \\
\hline
\end{tabular}

Keterangan : $\mathrm{n}$ : tidak berbeda nyata, Pr: probability, BSP: Bulan setelah perlakuan.

Hasil statistik menunjukkan perlakuan berbagai dosis pupuk $\mathrm{Ca}$ tidak memberikan pengaruh terhadap panjang pelepah (Tabel 5). Walaupun secara statistik tidak memberikan pengaruh nyata, pada perlakuan Ca1 dengan dosis $0.6 \mathrm{~kg}$ kalsium pertanaman pada $12 \mathrm{BSP}$ cenderung lebih tinggi $3.3 \%$ dibanding dengn kontrol. Perbandingan Ca1 pada 12 BSP cenderung lebih tinggi terhadap perlakuan $\mathrm{Ca} 2$ dan $\mathrm{Ca} 3$. Perbedaan Ca1 terhadap $\mathrm{Ca} 2$ sebesar $8.6 \%$ dan $10.6 \%$ dengan Ca3.

Tabel 5 Panjang pelepah tanaman sawit pada berbagai dosis kalsium

\begin{tabular}{|c|c|c|c|c|c|c|c|c|c|c|c|c|}
\hline \multirow{2}{*}{$\begin{array}{l}\text { Kalsium } \\
\text { (kg/pokok) }\end{array}$} & \multicolumn{12}{|c|}{ Panjang pelepah $(\mathrm{cm})$ pada BSP } \\
\hline & 1 & 2 & 3 & 4 & 5 & 6 & 7 & 8 & 9 & 10 & 11 & 12 \\
\hline 0 & 134.7 & 125.7 & 129.5 & 139.3 & 145.4 & 141.2 & 142.5 & 139.3 & 138.3 & 149.7 & 153.7 & 160.6 \\
\hline 0.6 & 113.1 & 117.8 & 132.3 & 143.6 & 155.3 & 155.0 & 150.5 & 148.6 & 150.4 & 155.3 & 161.3 & 165.9 \\
\hline 1.2 & 137.4 & 143.2 & 136.4 & 141.3 & 146.4 & 148.2 & 144.8 & 137.2 & 141.2 & 145.6 & 152.8 & 152.8 \\
\hline 2.3 & 154.8 & 154.1 & 136.3 & 145.1 & 153.7 & 152.1 & 153.7 & 145.2 & 147.0 & 148.9 & 151.9 & 150.0 \\
\hline Notasi & tn & tn & tn & tn & tn & tn & tn & tn & tn & tn & tn & tn \\
\hline
\end{tabular}

Keterangan : tn : tidak berbeda nyata, BSP: Bulan setelah perlakuan.

Pemberian pupuk Ca tidak memberikan pengaruh terhadap luas daun tanaman (Tabel 6). Hasil yang didapatkan pada perbandingan perlakuan tanpa perlakuan kalsium dan perlakuan lain pada 12 BSP tidak berbeda. Tanpa pemberian pupuk tanaman mampu menghasilkan luas daun baik.

Laju pertumbuhan pada berbagai perlakuan menghasilkan rata-rata pengamatan pada setiap peubah cenderung sama, artinya perbedaan perlakuan kalsium tidak memberikan pengaruh terhadap pertumbuhan tanaman. Hal ini sejalan dengan Ramadhaini (2013) bahwa penggunaan pupuk majemuk yang mengandung $\mathrm{N}, \mathrm{P}$, dan $\mathrm{K}$ lebih berpengaruh terhadap hasil dibandingkan penggunaan kapur pertanian. Hal ini dapat dipengaruhi oleh beberapa faktor lingkungan. Selain itu, pemberian Ca belum bisa merangsang penyerapan unsur hara esensial yang dibutuhkan oleh tanaman. 
Tabel 6 Luas daun tanaman sawit pada berbagai dosis kalsium

\begin{tabular}{|c|c|c|c|c|c|c|c|c|c|c|c|}
\hline \multirow{2}{*}{$\begin{array}{c}\text { Kalsium } \\
\text { (kg/pokok) }\end{array}$} & \multicolumn{11}{|c|}{ Panjang pelepah $(\mathrm{cm})$ pada BSP } \\
\hline & 1 & 2 & 3 & 4 & 5 & 6 & 7 & 9 & 10 & 11 & 12 \\
\hline 0 & 2600.0 & 2849.9 & 1545.1 & 3514.7 & 4842.0 & 5968.1 & 6367.9 & 5708.45670 .7 & 6632.0 & 5911.9 & 7290.0 \\
\hline 0.6 & 3073.1 & 3184.6 & 1747.6 & 3644.1 & 5147.6 & 6061.6 & 6453.4 & 5992.85892 .4 & 6932.8 & 5759.0 & 6907.0 \\
\hline 1.2 & 2883.9 & 3678.2 & 1903.5 & 3697.6 & 5438.0 & 6175.5 & 6449.5 & 5471.35731 .4 & 6324.5 & 6406.7 & 7188.0 \\
\hline 2.3 & 2720.6 & 3467.9 & 1720.3 & 3424.6 & 4672.2 & 6123.0 & 6265.3 & 5589.06059 .1 & 6765.1 & 6632.9 & 6759.0 \\
\hline Notasi & tn & tn & tn & tn & tn & tn & tn & tn & tn & tn & tn \\
\hline
\end{tabular}

Keterangan : tn : tidak berbeda nyata, BSP: Bulan setelah perlakuan.

Peubah yang diamati pada fisiologi tanaman adalah tingkat kehijauan daun. Hasil dari berbagai perlakuan kalsium tidak memberikan peningkatan tingkat kehijauan daun pada masing-masing bulan pengamatan (Tabel 7). Hasil percobaan menunjukkan pada 3 BSP, rataan hijau daun sebesar 62.5. Kondisi tersebut mengalami penurunan pada 6 BSP yang menghasilkan rataan hijau daun sebesar 60.7. Penurunan tingkat kehijauan daun berarti kondisi daun tidak mampu mengoptimalkan serapan sinar matahari pada bulan tersebut. Kondisi tersebut dapat mempengaruhi pola pertumbuhan pada tanaman. Data pengamatan terakhir yang dilakukan pada 9 BSP menunjukan peningkatan menjadi 66.9. Namun, pada pemberian pupuk $\mathrm{Ca}$ dosis $1.2 \mathrm{~kg}$ dan $2.3 \mathrm{~kg}$ (67.1) cenderung lebih tinggi dibandingkan tanpa $\mathrm{Ca}(66.6)$.

Secara umum pemberian pupuk kalsium tidak memberikan pengaruh pada tingkat kehijauan daun. Pengamatan pada 9 BSP menunjukkan bahwa tingkat kehijauan daun cenderung paling tinggi pada perlakuan $\mathrm{Ca} 20.8 \%$ dan $\mathrm{Ca} 3 \quad 0.8 \%$ dibandingkan dengan kontrol. Tingkat kehijauan daun merupakan tampilan visual yang berkorelasi terhadap kandungan klorofil (Yudiwanti et al 2008). Tingkat kehijauan daun adalah salah satu indikator terhadap proses fotosintesis pada tanaman. Tingkat fotosintensis yang baik memberikan pengaruh terhadap pertumbuhan tanaman.

Tabel 7. Tingkat kehijauan daun tanaman sawit pada berbagai dosis kalsium

\begin{tabular}{cccc}
\hline \multirow{2}{*}{\begin{tabular}{c} 
Perlakuan \\
\cline { 2 - 4 }$(\mathrm{kg})$
\end{tabular}} & \multicolumn{3}{c}{ Tingkat kehijauan pada bulan ke- } \\
\hline 0 & $3 \mathrm{BSP}$ & $6 \mathrm{BSP}$ & $9 \mathrm{BSP}$ \\
0.6 & 62.7 & 61.1 & 66.6 \\
1.2 & 62.6 & 61.6 & 66.8 \\
2.3 & 61.6 & 56.5 & 67.1 \\
\hline Notasi & 62.9 & 63.4 & 67.1 \\
\hline
\end{tabular}

Keterangan : tn : tidak berbeda nyata, BSP: Bulan setelah perlakuan.

\section{Analisis Jaringan Tanaman dan Analisis Tanah}

Analisis jaringan daun dilakukan dengan tujuan untuk mengetahui kandungan hara yang dapat diserap oleh tanaman. Kandungan hara daun yang diserap tanaman memiliki hubungan dengan pertumbuhan tanaman sehingga digunakan sebagai salah satu dalam menyusun rekomendasi pemupukan pada masa berikutnya (Winarna et al., 2005). Hasil analisis jaringan daun terhadap berbagai pemberian dosis kalsium tidak berpengaruh nyata terhadap kandungan kalsium dalam daun (Tabel 8).

Tabel 8. Kadar kalsium dalam daun

\begin{tabular}{cc}
\hline Kalsium $(\mathrm{kg} /$ pokok $)$ & Ca dalam daun \\
\hline 0 & 0.31 \\
0.6 & 0.29 \\
1.2 & 0.31 \\
2.3 & 0.31 \\
\hline Notasi & tn
\end{tabular}

Hasil analisis sampel tanah akhir diambil pada setiap perlakuan dan ulangan dari piringan tanaman contoh. Pengambilan dilakukan pada akhir penelitian, bulan Maret 2014, setelah pemupukan kedua bulan Januari 2014. Hasil analisis satatistik diperoleh perbedaan nyata pada berbagai perlakuan kalsium yang diberikan (Tabel 9). Perbandingan Ca3 (2.3 kg) dengan Ca1 $(0.6 \mathrm{~kg})$ sebesar $86.1 \%, \mathrm{Ca} 3(2.3 \mathrm{~kg})$ dibandingkan dengan $\mathrm{Ca} 2(1.2 \mathrm{~kg})$ diperoleh hasil sebesar $88.7 \%$, perbandingan antara $\mathrm{Ca} 3$ $\left(\begin{array}{lllllll}2.3 & \mathrm{~kg}\end{array}\right)$ dengan $\mathrm{Ca} 0 \quad(0 \mathrm{~kg})$ sebesar 143.6 $\%$. Dengan demikian, kandungan kalsium dalam tanah paling tinggi pada $10 \mathrm{BSP}$ pada dosis $2.3 \mathrm{~kg}$ piringan.

Tabel 9. Kadar kalsium dalam tanah

\begin{tabular}{cc}
\hline Kalsium $(\mathrm{kg} /$ pokok $)$ & $\begin{array}{c}\text { Ca dalam tanah } \\
(\mathrm{mmol} / 100 \mathrm{~g})\end{array}$ \\
\hline 0 & 5.463 \\
0.6 & 7.233 \\
1.2 & 7.103 \\
2.3 & 13.443 \\
\hline Notasi & $\mathrm{L}^{*}$
\end{tabular}


Kondisi tanah setelah pemupukan responsif terhadap pemberian kalsium. Analisis regresi pada umur $12 \mathrm{BSP}$ atau 2 bulan setelah pemupukan kedua perlakuan kalsium membentuk respon linier. Hal tersebut menunjukkan dengan penambahan dosis kalsium, kandungan kalsium di dalam tanah akan meningkat. Secara umum pada perlakuan kalsium pada berbagai taraf menunjukkan hasil kandungan kalsium tanah

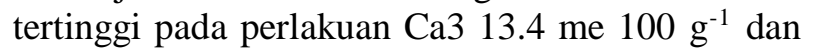
koefisien korelasi $\left(\mathrm{R}^{2}\right)$ sebesar $76 \%$. Pemupukan kalsium memberikan peningkatan kandungan kalsium di dalam tanah. Perbandingan kandungan kalsium pada hasil analisis tanah awal dan tanah akhir mengalami penurunan pada perlakuan kontrol sebanyak $28 \%$ dalam setahun.

\section{KESIMPULAN}

Hasil penelitian menunjukan pemupukan kalsium pada dosis 0 hingga $2.3 \mathrm{~kg}$ selama 1 tahun tidak berpengaruh nyata terhadap laju pertumbuhan dan fisiologi tanaman. Peubah fisiologi tanaman pada analisis jaringan tanaman menunjukkan kandungan kalsium dalam daun kritis. Kondisi tersebut menunjukkan bahwa pupuk kalsium yang diberikan lambat tersedia oleh tanaman sehingga kandungan kalsium dalam jaringan tanaman menunjukkan kritis hara kalsium. Namun demikian, selama penelitian tidak menunjukkan adanya gejala defisiensi hara, hal ini diduga ada mekanisme lain sehingga terjadi perbedaan status hara daun dengan status hara tanah. Hal tersebut membutuhkan penelitian lanjutan.

\section{DAFTAR PUSTAKA}

Mattjik, A.A., Sumertajaya, I.,M. 2006. Perancangan Percobaan dengan Aplikasi SAS dan MINITAB. Bogor (ID): IPB Press.
Pahan, I. 2007. Kelapa Sawit Manajemen Agribisnis Dan Hulu Hingga Hilir. Jakarta (ID): Penebar Swadaya.

[PPT] Pusat Penelitian Tanah. 2008. Kriteria Penilaian Data Analisis Sifat Kimia Tanah. Jakarta (ID): Departemen Pertanian.

Plaster, E.J. 1992. Soil Science and Management. Edisi ke-2. New York (USA): Delmar Publishers.

Ramadhaini, R, F. 2013. Optimasi dosis pupuk majemuk NPK dan kalsium Pada bibit kelapa sawit (Elaeis guineensis Jacq.) di pembibitan utama [Tesis]. Bogor (ID): Institut Pertanian Bogor.

Risza, S. 2010. Masa Depan Perkebunan Kelapa Sawit Indonesia. Yogyakarta (ID): Kanisius.

Sutarta, E.S., Darmosarkoro, W. 2007. Penggunaan Pupuk Majemuk pada Perkebunan Kelapa Sawit. Darmosarkoro W, Sutarta ES, Winarna, editor. Lahan dan Pemupukan kelapa sawit edisi 1. Medan (ID): Pusat Penelitian Kelapa Sawit.

Winarna, Sutarta, E.S., Sugiyono. 2005. Pedoman Pengambilan Contoh Daun dan Tanah. Pusat Penelitian Kelapa Sawit, Medan.

Yudiwanti, Wirawan, B., Wirnas, D. 2007. Korelasi antara kandungan klorofil, ketahanan terhadap penyakit bercak daun dan daya hasil pada kacang tanah. Prosiding Seminar Nasional Bioteknologi dan Pemuliaan Tanaman Departemen Agronomi dan Hortikultura Faperta IPB: Bogor, 1-2 Agustus 2006. 